\title{
A mesocosm experiment investigating the effects of substratum quality and wave exposure on the survival of fish eggs
}

\author{
Stefan Stoll • Wolfgang Nikolaus Probst • \\ Reiner Eckmann · Philipp Fischer
}

Received: 12 May 2009/Accepted: 2 June 2010/Published online: 19 June 2010

(C) Springer Basel AG 2010

\begin{abstract}
In a mesocosm experiment, the attachment of bream (Abramis brama) eggs to spawning substrata with and without periphytic biofilm coverage and their subsequent survival with and without low-intensity wave exposure were investigated. Egg attachment was reduced by $73 \%$ on spawning substrata with a natural periphytic biofilm, compared to clean substrata. Overall, this initial difference in egg numbers persisted until hatching. The difference in egg numbers was even increased in the wave treatment, while it was reduced in the no-wave control treatment. Exposure to a low-intensity wave regime affected egg development between the two biofilm treatments differently. Waves enhanced egg survival on substrata without a biofilm but reduced the survival of eggs on substrata with biofilm coverage. In the treatment combining biofilm-covered substrata and waves, no attached
\end{abstract}

S. Stoll $(\bowtie) \cdot$ W. N. Probst $\cdot$ R. Eckmann $\cdot$ P. Fischer

Limnological Institute, University of Konstanz,

78457 Constance, Germany

e-mail: Stefan.Stoll@uni-konstanz.de

Present Address:

S. Stoll

Department of Limnology and Conservation, Research Institute

Senckenberg, 63571 Gelnhausen, Germany

Present Address:

W. N. Probst

Johann Heinrich von Thünen-Institute of Baltic Sea Fisheries,

Alter Hafen Süd 2, 18069 Rostock, Germany

Present Address:

P. Fischer

Alfred-Wegener-Institute for Polar and Marine Research,

Biologische Anstalt Helgoland, Kurpromenade 201,

27498 Helgoland, Germany eggs survived until hatching. In all treatments, more than $75 \%$ of the eggs became detached from the spawning substrata during the egg incubation period, and $<1 \%$ of these detached eggs survived within the substratum interstices. Hence, detached eggs contributed little to the reproductive success we observed. The implications of these results on the spawning success of fish species that use freshly inundated spawning substrata in shallow waters are discussed.

Keywords Common bream Abramis brama . Spring water level increase - Periphytic biofilm . Surface waves $\cdot$ Egg attachment $\cdot$ Egg survival

\section{Introduction}

The egg stage is a critical bottleneck for many fish species, and egg survival is a major factor affecting year class strength (Gafny et al. 1992; Fitzsimons et al. 2007; Probst et al. 2009). Knowledge about biotic and abiotic factors mediating egg survival, therefore, is important for the management of fish stocks and fish population modelling.

A common strategy to improve egg survival is to select a spawning habitat that ensures good conditions for egg development. In many species, eggs are attached to appropriate structures, preventing their relocation to less favourable habitats (Zeh et al. 1989; Spence et al. 2007; Steer and Moltschaniwskyj 2007). In lakes, these structures are most commonly found in the littoral zone and include plant material, woody debris, and bottom substrata (Fisher et al. 1996; Poncin et al. 1996).

Sticky eggs adhere better to clean surfaces than to surfaces covered with periphytic biofilm (Gafny et al. 1992; Probst et al. 2009). A preference for spawning substrata 
without biofilm and enhanced egg survival rates associated with low biofilm coverage have been recorded for several species, including lake sardines (Acanthobrama terraesanctae) (Gafny et al. 1992), yellow perch (Perca flavescens) (Fisher et al. 1996), and bream (Abramis brama) (Probst et al. 2009). Some fish species also clean their spawning substratum before spawning, either by mouth or using tail beating (Thorp 1988; Bruton and Gophen 1992). Another common strategy is to spawn soon after a rise in water level (Gafny et al. 1992; Ali and Kadir 1996; Ozen and Noble 2002) because no biofilm has yet developed on freshly inundated substrata. Because periphytic biofilm can develop within 14 days or less (Gafny et al. 1992; Peters et al. 2007), the window of opportunity in which fishes that spawn in shallow water can benefit from biofilm-free substrata is narrow.

In many temperate and boreal areas, the hydrological regimes of freshwater systems show distinct annual fluctuations: In winter, water levels are low because precipitation in the catchment area is withheld as snow, and in spring and early summer, water levels increase due to spring snowmelt. This water level increase creates freshly inundated habitats in a predictable spatial and temporal framework, which are utilised by many fish species for spawning (Rupp 1965; Nõges and Järvet 2005; Probst et al. 2009).

Waves also have the potential to affect the reproductive success of fish. Studies on the effects of waves have, so far, focused predominantly on severe impacts of waves, such as temporary dewatering of fish eggs and larvae by shipinduced water level drawdown (Holland 1986, 1987; Niepagenkemper 2004). Less attention has been paid to less drastic, long-range effects of ships. In large lakes, ships pass the shore at a distance of several hundred meters, but their waves can travel several kilometres, and thus can reach even remote shorelines (Hofmann et al. 2008). Even though the energy flux of these waves is low, they may be ecologically relevant, especially in combination with biofilm coverage on spawning substrata, which impedes egg attachment (Probst et al. 2009).

This mesocosm experiment investigated the combined effects of biofilms and low-intensity waves on the survival of eggs of shallow water spawning fish, using bream (Abramis brama) as a model species. Three particular questions were raised:

1. Does biofilm coverage affect egg attachment on a natural spawning substratum?

2. Is hatching success on a biofilm-covered and a biofilmfree natural spawning substratum mediated by a realistic low-intensity wave scenario?

3. How much do detached eggs contribute to total egg survival?
By answering these questions, this study aimed at improving our understanding of the environmental factors regulating year class strength, which is necessary to understand the demographic dynamics of fish populations. Furthermore, knowledge of the mechanistic responses of organisms to environmental variables is necessary to predict the reaction of these organisms to a changing environment.

\section{Materials and methods}

\section{Model species}

Bream were used as a model species for fish with sticky eggs that spawn in the spring in shallow waters. Bream are common in temperate parts of Europe, where they predominantly occur in mesotrophic to eutrophic lakes and in the potamal sections of rivers, but also in oligotrophic lakes such as Lake Constance (Löffler 1984). In their distribution range, bream spawn between April and June, depending on latitude, which is correlated with water temperature (Backiel and Zawisza 1968). In Lake Constance, where this experiment was performed, the spawning period usually lies between the end of April and the middle of May. During this period, aggregations of mature bream enter the littoral zone and spawn at water depths shallower than $40 \mathrm{~cm}$ (Wittkugel 2002). Bream generally prefer cobble or gravel beaches and submerged or emergent vegetation for spawning (Poncin et al. 1996). In many large pre-alpine lakes, submerged vegetation is typically absent during the bream spawning period, and bream spawn on non-vegetated cobble beaches. These conditions were simulated in this mesocosm experiment. However, as almost all kinds of spawning substrata develop a biofilm layer on their surfaces (Albay and Akcaalan 2003), the results of this study should be transferable to other spawning substrata as well.

\section{Experimental setup}

Experiments were conducted in May 2007, using two identical outdoor mesocosms with base dimensions of $10 \times 1 \mathrm{~m}$ and a water depth of $0.9 \mathrm{~m}$. A slope was installed at one end of each mesocosm. The slope was formed by a metal grid covered with canvas and topped by a $5 \mathrm{~cm}$ thick layer of gravel (grain size 1-2 cm). The slope was divided into an upper and lower section, separated at $0.2 \mathrm{~m}$ water depth by a $1 \mathrm{~m}$ long horizontal plateau. The upper slope rose above the water level (Fig. 1a). In one mesocosm, an air pressure driven wave generator was installed at the non-sloping end. The second mesocosm served as a no-wave control. Six wave pulses per hour of 
Fig. 1 a Setup of the wave mesocosm. A second, identical mesocosm without a wave machine was used for the nowave control treatment. b Design of the trays. Six cobbles, which were used as spawning substrata, were embedded in sediment from the upper littoral zone of Lake Constance. Three cobbles per tray were covered with biofilm (dark grey), three cobbles were bare (white). A mark at one corner of the tray identified each tray and gave each cobble an individually identifiable position in the tray

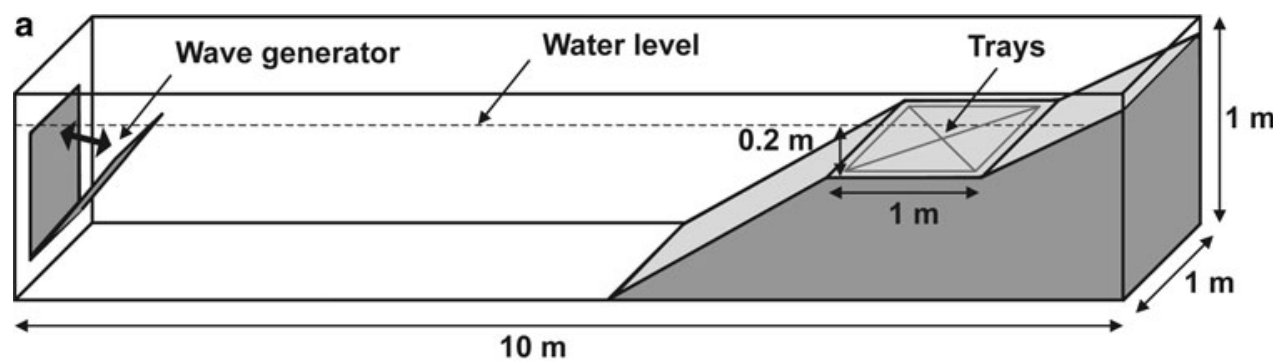

b

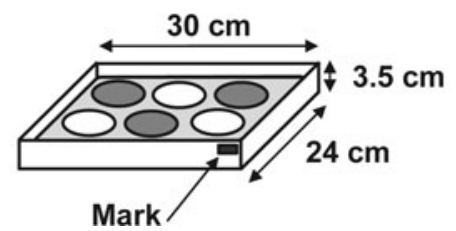

3-min duration each were created between 9:00 and 20:00 $\mathrm{h}$, and two pulses per hour of $3 \mathrm{~min}$ duration were created between 20:00 and 9:00 h. The wave period $(T)$ was $1.2 \mathrm{~s}$; maximum current velocities $\left(u_{\max }\right)$ were 0.3 to $0.4 \mathrm{~m} \mathrm{~s}^{-1}$ at $0.2-\mathrm{m}$ water depth, resulting in energy fluxes $\left(E_{\mathrm{F}}\right)$ of approximately $20 \mathrm{~W} \mathrm{~m}^{-1}$. This regime mimicked a moderately exposed area of the shore of Lake Constance as realistically as possible with respect to number of wave events caused by scheduled ship traffic, energy flux by ship waves $\left(E_{\mathrm{F}}=14 \mathrm{~W} \mathrm{~m}^{-1}\right.$ in April, $25 \mathrm{~W} \mathrm{~m}^{-1}$ in May) and maximum current velocities $\left(u_{\max } \approx 0.4 \mathrm{~m} \mathrm{~s}^{-1}\right)$ (Hofmann 2007; Hofmann et al. 2008). The wave period of $1.2 \mathrm{~s}$, however, was shorter in the mesocosm than at the reference site $(T=2.9-3.7 \mathrm{~s}$ for ferry and passenger ship waves) due to restrictions in the dimensions of the mesocosm.

The mesocosms were flow-through systems that were fed with lake water. The water inlet was situated on the sloping end of the mesocosm, and the outlet was at the opposite end. The flow rate was adjusted to maintain the water temperature as closely as possible to $14^{\circ} \mathrm{C}$, ensuring optimal bream egg development (Herzig and Winkler 1986). The water exchange rate ranged between 0 and $5.4 \mathrm{~L} \mathrm{~min}^{-1}$, the latter corresponding approximately to a complete change of water in the mesocosm during a period of $24 \mathrm{~h}$. To prevent thermal stratification, particularly in the no-wave control, both mesocosms were aerated by compressed air and limestone diffusers in the lower slope area, creating a constant water circulation. Actual temperatures throughout the experiment were $14.0 \pm 1.3^{\circ} \mathrm{C}$ in the plateau area of the wave mesocosm and $14.7 \pm 1.1^{\circ} \mathrm{C}$ in the plateau area of the no-wave control (mean $\pm \mathrm{SD}$ ). This temperature difference proved to be insignificant (paired $t$ test: $n=18, d f=1, t=1.05, p=0.34$ ).

Twenty-four trays with base dimensions of $30 \times 24 \mathrm{~cm}$ and a height of $3.5 \mathrm{~cm}$ were filled to a depth of $2-3 \mathrm{~cm}$ with natural bottom substratum, including all of its bacterial, algal and invertebrate biota, from the upper eulittoral zone of Lake Constance. Grain size composition [fraction $f$ (mm), contribution $c(\%$, mean $\pm \mathrm{SD}), n=3, m=250 \mathrm{~g}$ per sample) was $f<0.63: c=5.5 \pm 4.2 ; f=0.63-2.0$ : $c=17.5 \pm 11.3 ; f=2.0-6.3: c=4.2 \pm 0.3 ; f=6.3-20$ : $c=72.8 \pm 15.5$. Six cobbles of $9-11 \mathrm{~cm}$ diameter and $3-5 \mathrm{~cm}$ height were embedded in each substratum tray. The trays were pre-exposed to water in Lake Constance at $30 \mathrm{~cm}$ water depth from 14 March 2007 until the beginning of the experiment on 8 May 2007 so that all substratum surfaces were able to develop a natural periphytic biofilm. The position of the trays was continually adjusted so that they remained at $30 \mathrm{~cm}$ water depth during the entire exposure period in the lake. The developing periphytic biofilm mainly consisted of benthic diatoms, heterotrophic bacteria and cyanobacteria. On 8 May 2007, the trays were removed from the lake and placed in a lake water tank to prepare the different experimental substrata conditions. One half of the embedded cobbles were allowed to retain their biofilm, while the other half was cleaned by brushing. To test the efficacy of cleaning, the biofilm on 20 cobbles was sampled before and after brushing with a brush suction sampler as described in Peters et al. (2005). The samples were filtered on glass fibre filters, and ash-free dry mass (AFDM) and inorganic matter content (IM) were determined. Before brushing, AFDM of $0.53 \pm 0.18 \mathrm{mg} \mathrm{cm}^{-2}$ $\left(\right.$ mean $\pm \mathrm{SD}$ ) and IM of $11.5 \pm 7.0 \mathrm{mg} \mathrm{cm}^{-2}$ were present on the cobbles. Brushing cobbles was shown to remove $95 \%$ of total biofilm mass, with $0.15 \pm 0.07 \mathrm{mg} \mathrm{cm}^{-2}$ of AFDM and $0.43 \pm 0.34 \mathrm{mg} \mathrm{cm}^{-2}$ of IM remaining.

\section{Experiment procedures}

Adult bream were caught in Lake Constance by gill- and trap-netting in April 2007 and kept in a $13 \mathrm{~m}^{3}$ flow-through outdoor tank. On the morning of 9 May 2007, all cobbles were placed randomly in shallow containers filled with lake water to a depth of $25 \mathrm{~cm}$. Eggs and milt were stripped from two female and two male bream, respectively, and 
mixed to fertilise the eggs. The fertilised eggs were then sprinkled evenly over all cobbles in the containers. Subsequently, the cobbles were allowed to rest in the containers for $2 \mathrm{~h}$ to allow the adhesion of the eggs. Then, the number of eggs adhering to each individual cobble was counted, and six cobbles were placed back in each substratum tray, three with biofilm coverage and three without (Fig. 1b). Trays were marked and the position of each cobble within a tray was noted, such that individual cobbles could be identified throughout the experiment. The trays were introduced carefully into the two mesocosms and placed on the horizontal plateau at $0.2 \mathrm{~m}$ water depth (Fig. 1a).

On the morning of the first, third, sixth and ninth day of the experiment, three randomly chosen trays were carefully sampled from each mesocosm. The viable and dead eggs on each individual cobble were counted. Eggs were classified by eye as being viable, if they were clear, or from day 3 onwards, they were classified as to whether an embryo was visible inside. Eggs that were opaque or had ruptured shells were considered to be dead (Oyen et al. 1991). The cobbles were removed from the trays, and the substratum within each tray was examined for detached eggs, which were also counted and identified as viable or dead. By day 9, almost all of the remaining eggs had hatched. This final sampling confirmed that the predicted incubation period of 7.1-8.0 day that has been calculated for bream eggs at average temperatures of $14.0-14.7^{\circ} \mathrm{C}$ by Herzig and Winkler (1986) was met and that egg development was normal. Thus, eggs that were viable on day 6 were regarded as having survived until hatching, and samples taken at day 9 were not used for statistical analysis. Therefore, a total of only 18 trays (day 1, 3 and 6) with six cobbles each were used in the statistical analysis.

In a separate experiment, the decay of dead eggs was investigated. Five polyethylene beakers $(\varnothing=5 \mathrm{~cm}$, $100 \mathrm{ml}$ ) were filled with the same substratum that was used in the trays to a height of $2-3 \mathrm{~cm}$. The beakers were placed in a water bath at a constant temperature of $14^{\circ} \mathrm{C}$, and water exchange was provided by permanent dripping of lake water into the beakers. Twenty unfertilised bream eggs were placed into each beaker, and from day 2 onwards, each beaker was carefully checked daily for remaining eggs. Unfertilised eggs were used because no freshly dead intact fertilised bream eggs could be obtained. It was assumed that unfertilised and fertilised dead bream eggs decay at the same rate.

\section{Statistics}

Initial egg attachment was analysed with the Wilcoxon test. The fate of attached eggs until hatching was analysed using a generalised linear model (GLM) with binomial errors. Individual cobbles were used as replicates, and binomial data included the counts of viable eggs and the difference between initially attached eggs and the present number of viable eggs at the time of sampling. The analysis started with a full factorial model containing egg development time (1, 3, 6 days post fertilisation), periphytic biofilm coverage (biofilm, clean) and wave treatment (wave, no wave) as independent variables. Using the 'step' routine in the statistical software package $R$, the complexity of the GLM was reduced, stepwise, until a minimal Akaike Information Criterion (AIC) was achieved.

The effects of biofilm and waves on hatching success, i.e., survival at day 6 post fertilisation, were tested with Wilcoxon-tests. For the analysis of total survival, the numbers of surviving attached and detached eggs were summed. To make the survival of attached and detached eggs comparable on the basis of eggs per cobble, the viable eggs that were found in the interstitial space of the substratum of each tray were assigned to the individual cobbles in that tray according to the number of eggs that had been attached to them at the start of the experiment.

We are aware that, with only two mesocosms, our replicates are not fully independent, but rather in a strict sense, they are pseudoreplicates (Hurlbert 1984). This may be relevant, as pathogens that affect eggs may spread between the replicates within a mesocosm. However, as only two identical mesocosms were available, this flaw in the experimental design could not be avoided. The experiment could also not be replicated temporally as bream eggs were only available once.

\section{Results}

\section{Mesocosm experiment}

\section{Egg attachment}

The mean number of eggs that initially attached to clean cobbles was 3.7 times higher than the number adhering to cobbles with biofilm coverage (Fig. 2), with $86.1 \pm 67.5$ and $23.5 \pm 21.6$ eggs per cobble (mean $\pm \mathrm{SD}$ ), respectively (Wilcoxon, $n=108, d f=1, z=6.3, p<0.001$ ). Egg attachment was highly variable between replicate cobbles because each replicate consisted of a natural cobble differing in rock type and shape. Eggs adhered better to flat or concave areas of cobbles and less well to convex parts of the surfaces.

\section{Egg development}

In all treatments, only a small fraction of eggs remained attached and survived until hatching (Fig. 3a-d). Some eggs died but remained attached, and a small fraction of the 


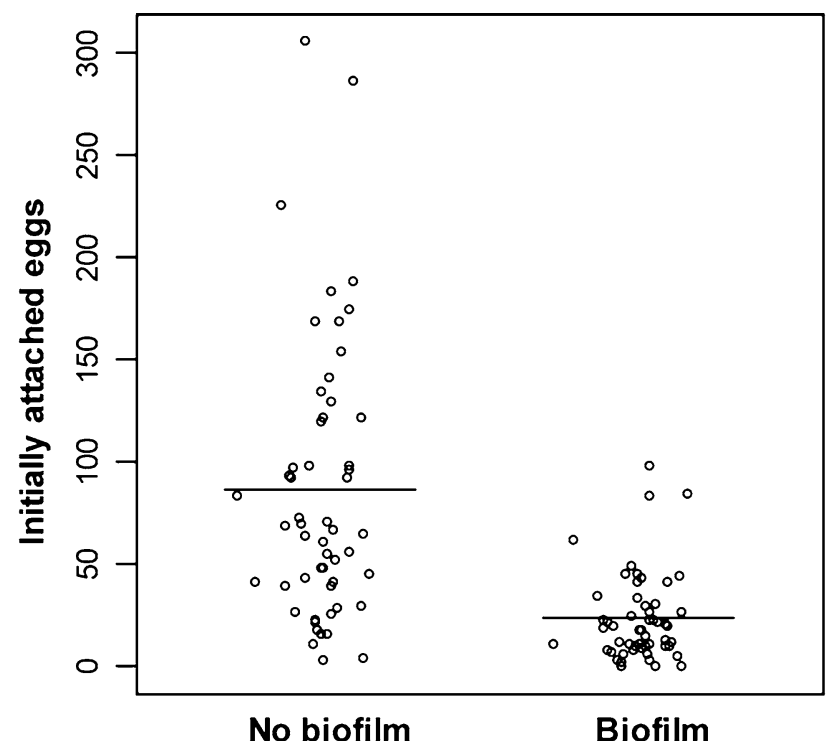

Fig. 2 Number of eggs initially attaching to cobbles with and without biofilm coverage. The lines give the mean values eggs was found alive or dead in the interstitial space of the substratum in the trays. However, the largest fraction of the eggs ( $>75 \%$ in all treatments) disappeared throughout the experiment.

Our GLM including all sampling days throughout egg development (days 1, 3, 6) showed that the proportion of viable eggs decreased significantly throughout the experiment (Fig. 4a, b; Table 1). Furthermore, throughout the period of egg development, more viable eggs were found on clean cobbles than on cobbles with biofilm coverage. For all cobbles and sampling days, significantly more viable eggs were found on cobbles with than without biofilm. Exposure to waves affected egg survival. However, the effect differed between clean cobbles and cobbles with biofilm, as indicated by the significant interaction term wave $\times$ biofilm. While waves had a detrimental effect on the development of attached eggs on cobbles with biofilm, they favoured egg development on clean cobbles (Fig. 4a, b; Table 1).
Fig. 3 Overview over the fate of the eggs throughout the experiment in the four treatment combinations biofilm-no wave (a), clean-no wave (b), biofilmwave (c), and clean-wave (d). Number of viable eggs (black), followed below by dead eggs (medium grey), viable detached eggs (dark grey) and dead detached eggs (light grey). The difference to the initial egg number (white) represents the number of eggs that disappeared throughout the experiment

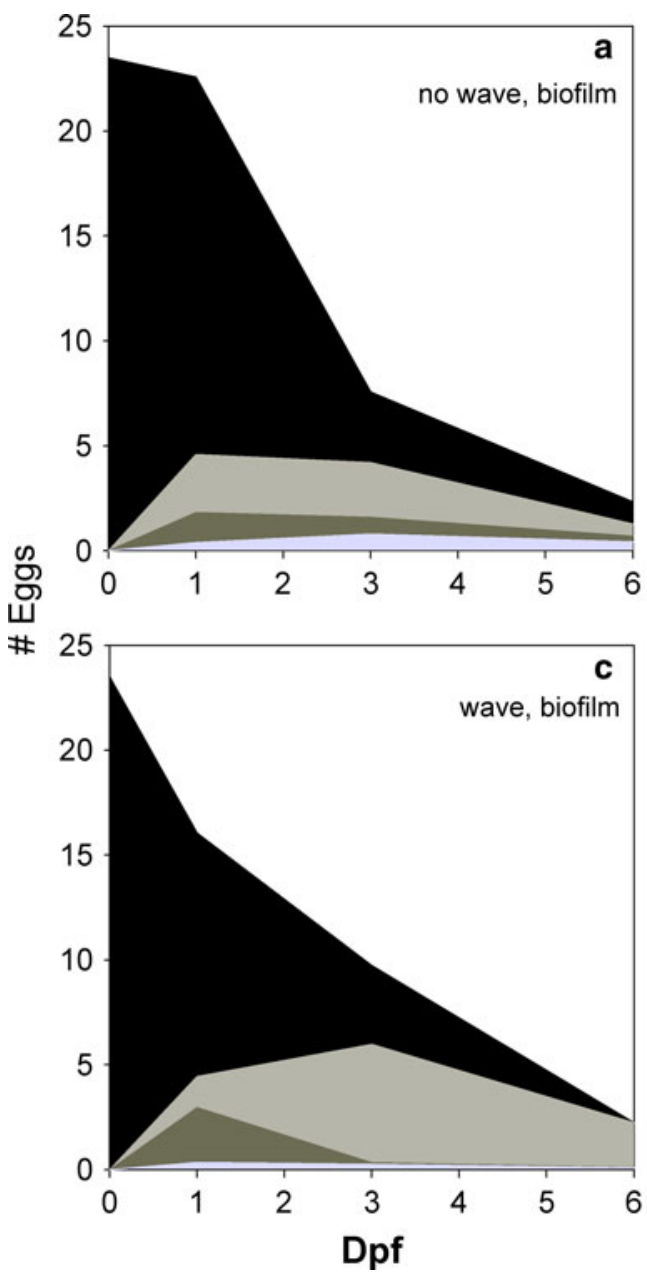

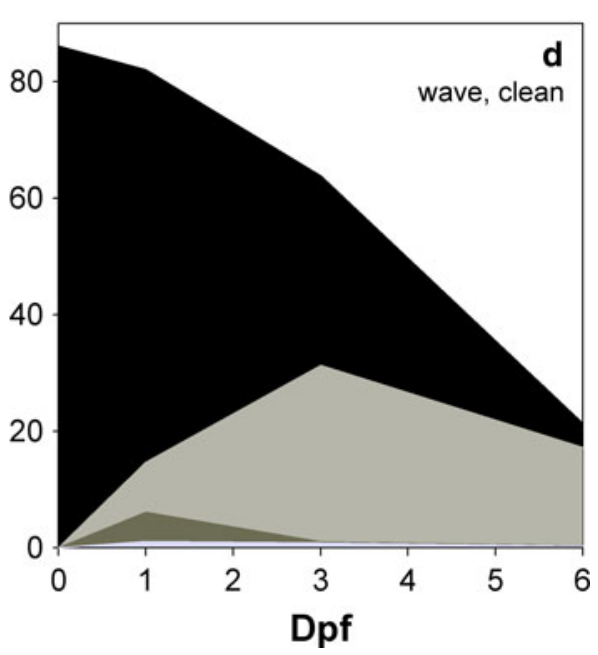


Fig. 4 a Number and b percentage of viable attached eggs per cobble throughout the experiment in the four treatment combinations with (white) and without (black) biofilm coverage and with (circle) and without (triangle) wave exposure. c Egg survival until hatching at day 6 post fertilisation (dpf6) between the four different treatment combinations. Survival of attached eggs on biofilmcovered (white) and clean (black) cobbles. Survival of detached eggs is added on top of each column (grey). Statistical results of Wilcoxon-tests are indicated. All values are mean $\pm \mathrm{SE}$
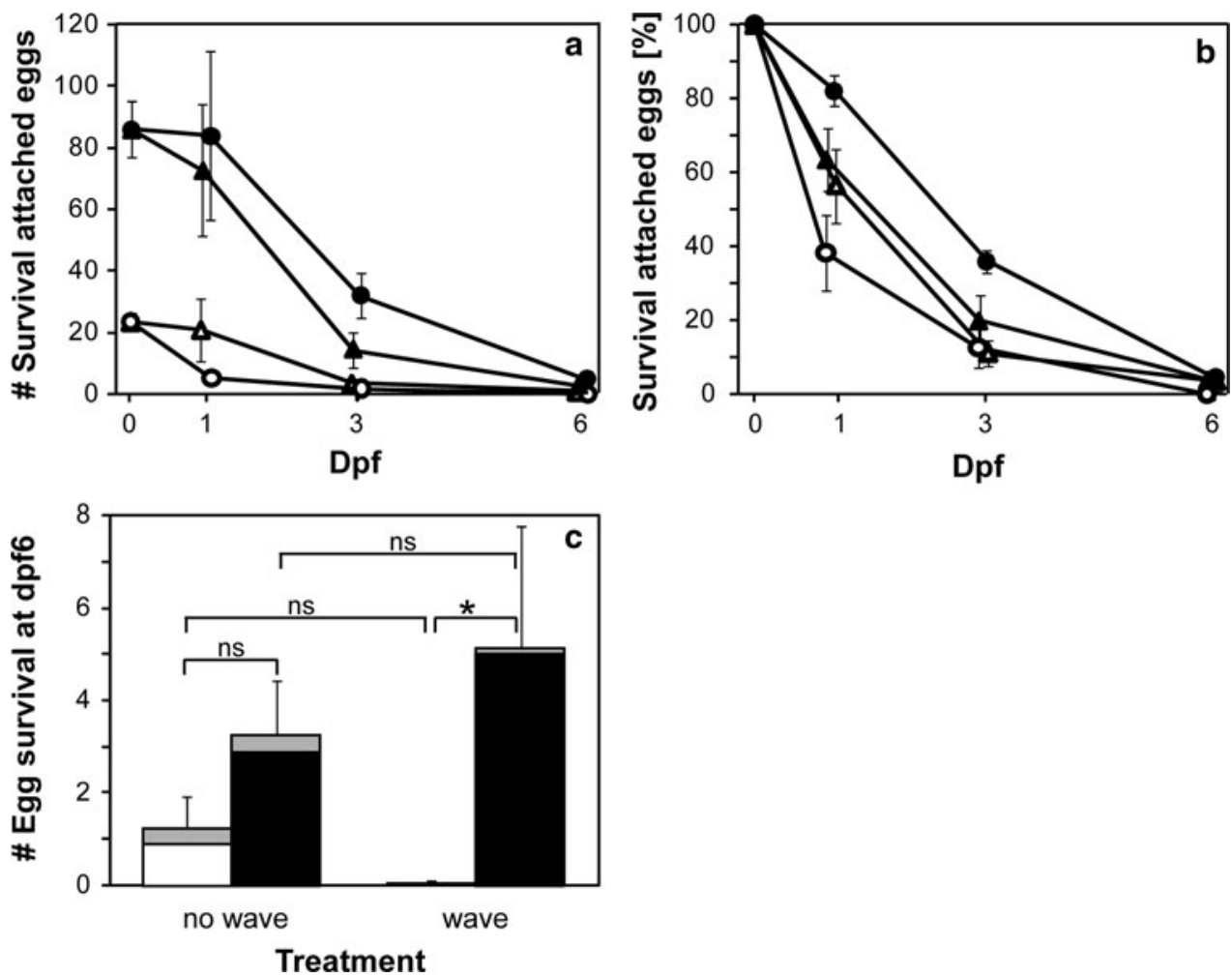

Table 1 Results of the generalised linear model with binomial errors analysing survival of attached eggs during the experiment

\begin{tabular}{llrr}
\hline Factors & $d f$ & \multicolumn{1}{l}{$Z$} & \multicolumn{1}{l}{$P$} \\
\hline Dpf & 1 & -23.9 & $<\mathbf{0 . 0 0 1}$ \\
Wave & 1 & -5.1 & $<\mathbf{0 . 0 0 1}$ \\
Biofilm & 1 & 4.5 & $<\mathbf{0 . 0 0 1}$ \\
Dpf $\times$ Wave & 1 & -1.4 & 0.153 \\
Wave $\times$ Biofilm & 1 & 9.5 & $<\mathbf{0 . 0 0 1}$
\end{tabular}

The model was reduced stepwise until the minimal Akaike Information Criterion of 1,081.3 was reached, $n=108$

$D p f$ days post fertilisation

\section{Hatching success}

Initial differences in the number of attached eggs between the biofilm-covered and clean cobbles persisted until hatching in the wave treatment (Wilcoxon: $n=18, d f=1$, $z=2.8, p=0.005$ ), while in the no-wave control, the initial difference in the number of eggs decreased, and there was only a non-significant trend of different hatching success between the biofilm-covered and clean cobbles (Wilcoxon: $n=18, d f=1, z=1.5, p=0.129$ ). The trend we observed was that waves decreased hatching success on cobbles with biofilm (Wilcoxon: $n=18$, $d f=1, z=-1.8, p=0.080)$, while no effect of waves could be found on clean cobbles (Wilcoxon: $n=18$, $d f=1, z=0.3, p=0.790)$.
From the large proportion of eggs that was detached throughout the experiment, only a very small fraction survived in the sediment interstices. The trend we observed was that fewer detached eggs survived in the wave treatment than in the no-wave control $(0.1 \pm 0.1 \%$ and $0.8 \pm 0.5 \%$, respectively (mean $\pm \mathrm{SE}$ ); the Wilcoxon test result on numerical survival of detached eggs per tray: $n=6, d f=1, z=1.7, p=0.099$ ).

Due to poor survival of detached eggs, total egg survival was virtually identical with the survival of attached eggs (Fig. 4c), and statistical analyses of total egg survival yielded the same results as the analyses of survival of attached eggs (Wilcoxon-tests).

\section{Egg decay experiment}

The egg decay experiment showed that dead eggs decayed quickly. No remains of eggs were found later than day 6 after the start of the experiment (Fig. 5).

\section{Discussion}

On clean cobbles, 3.7 times more eggs initially attached compared to biofilm-covered cobbles. Cobbles are the natural spawning substrata of bream in many lakes. Unlike previous studies that used artificial substrata (Gafny et al. 1992: bricks; Probst et al. 2009: ceramic tiles), egg 


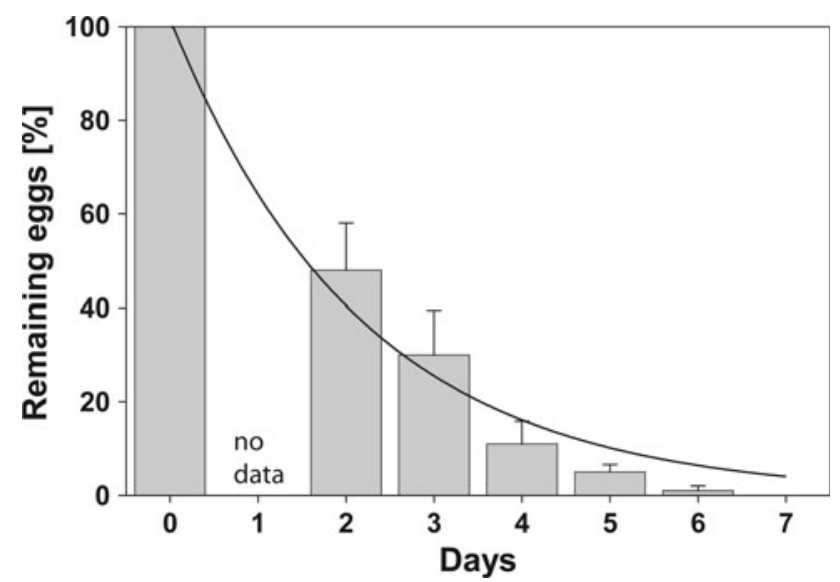

Fig. 5 Percentage of remaining eggs (mean \pm SE) in the egg decay experiment. An exponential decay model was fitted to the data, giving the percentage of remaining eggs $E_{R}$ as a function of time $t$. $E_{R}=102.15 \times e^{-0.4605 t} ; R^{2}=0.98$

attachment was highly variable between our replicate natural cobbles, which differed in rock type and shape. While the use of uniform substrata seems better suited to investigate the principal variables affecting egg survival, the use of natural substrata is required to quantify the effects of these variables in situ and to study their interactions. Data resulting from experiments using these natural substrata are best suited for fish stock management purposes. However, high variability in the data leads to statistically less clear patterns. Therefore statistical trends $(0.05<p<0.15)$ also are mentioned and discussed.

The effect of biofilms was largely limited to the inhibition of initial egg attachment, as the initial difference in the number of eggs between the cobbles with and without biofilm was virtually conserved throughout the whole experiment until hatching. Other studies have also reported negative effects of biofilms during the developmental period of eggs, e.g., due to allelopathic substances excreted by the biofilms (Oberemm et al. 1997; Probst et al. 2009) or a high prevalence of pathogens on biofilm-covered substrata (Gafny et al. 1992).

The effect of waves on egg survival rates of attached eggs differed between substrata with and without biofilm. Survival rates were increased by waves on biofilm-free substrata, while wave exposure hampered the egg survival rate on substrata with biofilm coverage. Thus, we hypothesise that waves detached eggs from the cobbles where they were not well attached due to the biofilm, while waves removed less eggs on clean cobbles, where eggs were more firmly attached. Steady water exchange around the eggs may have even improved the oxygen supply and reduced the accumulation of pathogens, leading to a higher survival rate of these eggs. However, at high current velocities and energy fluxes that can be caused by storms or by ships passing close to a spawning site, waves may also depress egg survival at sites with clean spawning substratum. Highintensity waves have already been shown to be an important habitat factor influencing egg survival of shallow water spawning fish (Rupp 1965; Fitzsimons et al. 2007).

In the wave treatment, the detrimental effect of the biofilm was preserved until hatching, as loosely attached eggs were washed off of the cobbles. In the no-wave treatment, egg survival on the natural cobbles was highly variable, obscuring the effect of the biofilm. Hence, no statistically significant difference could be found, but rather, only a trend could be seen. However, in the no-wave treatment, three times more eggs survived on clean than on biofilm-covered cobbles.

A large fraction of the eggs failed to attach to the cobbles or became detached during the experiment. Not all of these detached eggs necessarily die, as some may survive in the interstitial space of the substratum (Rupp 1965; Mills 1981; Gafny et al. 1992). However, in this experiment only $0.1 \pm 0.1 \%$ and $0.8 \pm 0.5 \%$ of the detached eggs survived in the wave and in the no-wave control treatments, respectively. Hence, the contribution of detached eggs to the total survival of eggs was low, and total egg survival was almost identical to the survival of the attached eggs. This result underlines that the selection of a suitable spawning site is crucial for a fish to maximise its reproductive success.

We observed a trend that fewer detached eggs survived in the wave compared to the no-wave treatment, probably because suspended particles abraded the eggs in the wave treatment, destroying them completely or making them more susceptible to pathogens or other harmful substances. Hofmann (2007) calculated that the waves generated in the type of mesocosm we used in these experiments are able to remobilise particles with a grain size of $1.2 \mathrm{~mm}$ at a water depth of $0.2 \mathrm{~m}$, which was characteristic of a considerable fraction of the substratum used in this study.

Overall, the rate of egg survival until hatching in the experiment was low. High egg mortality is typical for broadcast-spawning fish species with high egg numbers that do not exhibit parental care (Rupp 1965; Gafny et al. 1992; Zorn et al. 1998). Dead eggs have been shown to decay rapidly, which can explain the large proportion of the eggs that disappeared throughout these experiments.

The results of this study are relevant for the management of fish stocks that spawn in shallow waters. The spawning period of most of these fish coincides with water level increases. In Central Europe, regular and pronounced water level increases are commonly associated with snow melt in spring. Whether fish will spawn on substrata that are covered by biofilm or on freshly inundated pristine substrata without biofilm coverage depends on the amplitude of the water level increase shortly before the spawning 
period. The amplitude and timing of water level increases in spring is highly variable between years. At Lake Constance, which is a large (surface area $571 \mathrm{~km}^{2}$ ), unregulated pre-alpine lake, spring water level increases, measured as the difference in the mean water level in April and May, varied between -18 and $128 \mathrm{~cm}$ in the last 60 years (gauge Konstanz, ELWIS, Wasser- und Schifffahrtsverwaltung des Bundes). Maximum daily increases of $19 \mathrm{~cm}$, and weekly increases of $47 \mathrm{~cm}$, occurred in this period. In combination with variable wave exposure at the spawning sites, biofilm coverage can significantly influence the reproductive success of bream and other fish species that spawn in shallow water.

An increasing proportion of freshwater systems have become regulated to provide drinking and irrigation water, hydroelectric energy, or prevent flooding (Leira and Cantonati 2008). Because of this, water level fluctuations are increasingly buffered or artificially pulsed, disrupting adaptations to the natural dynamics of water levels in many species (Aroviita and Hämäläinen 2008; Sutela and Vehanen 2008). In fish that rely on biofilm-free spawning substrata, reproductive success may be impaired in such environments.

Climate change can also produce a mismatch between the spawning period of fishes and water level increases in spring. Spawning is often controlled by photoperiod (Potts and Wootton 1984; Dabrowski et al. 1996; Migaud et al. 2006) and is, therefore, highly fixed in timing, while the peak water level increase is currently shifted earlier in the year. Furthermore, in many regions, winter precipitation will be partially shifted from snow to rain. This will ultimately lead to greater runoff in winter and to earlier, less pronounced meltwater peaks in spring (Christensen et al. 2007).

This general forecast of large-scale climate models is congruent with regional predictions for southern Germany (KLIWA 2006), where the present study was performed. In Lake Constance, the winter water level has increased by approximately $2 \mathrm{~mm}$ per year since 1931. At the same time, summers have become drier, and average summer water levels have been reduced by approximately $5 \mathrm{~mm}$ per year (Ostendorp et al. 2004). These trends in Lake Constance are, at least partially, due to climate change (Jöhnk et al. 2004). Higher water levels in the winter and lower water levels in summer, which lead to a reduction in the amplitude of the water level increase in spring, will reduce suitable spawning habitats for spring shallow water spawning fish that rely on clean spawning substrata.

Wave exposure is also forecasted to increase in lakes in Europe and other regions worldwide. In many regions, stronger and more frequent wind events are predicted (KLIWA 2006; Christensen et al. 2007). Exposure to anthropogenic waves in addition to naturally occurring waves also is increasing because both commercial and recreational shipping intensities have grown in recent years (Mührle et al. 2004; European Commission 2006b) and are predicted to continue growing (European Commission 2006a). In some lakes, shipping already contributes more than $50 \%$ to the wave energy flux during parts of the year (Hofmann et al. 2008).

To date, most studies that have been conducted on the influence of climate change and other anthropogenic impacts on freshwater fish have focused on the direct effects of increasing temperature (Daufresne et al. 2003; Daufresne and Boët 2007; Sharma et al. 2007). The data presented in this study suggest that considering temperature alone may give an incomplete picture of the possible effects of climate change on local fish populations and that other factors, such as changes in hydrological and hydrodynamic regimes, should receive more attention.

Acknowledgments The authors thank P. Mahler, M. Wolf, J. Böhler and M. Schmid for help during the experiment. K. Rinke and B. Ferebee provided valuable help with statistical analyses. This study was conducted within the Collaborative Research Center 454 'Littoral Zone of Lake Constance', which was funded by the German Research Foundation (DFG) and a personal grant to S.S. by the German National Academic Foundation.

\section{References}

Albay M, Akcaalan R (2003) Comparative study of periphyton colonisation on common reed (Phragmites australis) and artificial substrate in a shallow lake, Manyas, Turkey. Hydrobiologia 506-509:531-540

Ali AB, Kadir B-KA (1996) The reproductive biology of the cyprinid, Thynnichthys thynnichthys (Bleeker), in the Chenderoh Reservoir-a small tropical reservoir in Malaysia. Hydrobiologia 318:139-151

Aroviita J, Hämäläinen H (2008) The impact of water-level regulation on littoral macroinvertebrate assemblages in boreal lakes. Hydrobiologia 613:45-56

Backiel T, Zawisza J (1968) Synopsis of biological data on the bream. FAO fisheries synopsis, vol 36, Rome, 143 pp

Bruton MN, Gophen M (1992) The effect of environmental factors on the nesting and courtship behaviour of Tilapia zillii in Lake Kinneret Israel. Hydrobiologia 239:171-178

Christensen JH, Hewitson B, Busuioc A (2007) Regional climate projections. In: Solomon S, Qin D, Manning M, Chen Z, Marquis M, Averyt KB, Tignor M, Miller HL et al (eds) Climate change 2007: the physical science basis. Contribution of working group I to the Fourth Assessment Report of the Intergovernmental Panel on Climate Change. Cambridge University Press, Cambridge, pp 849-940

Dabrowski K, Ciereszko RE, Ciereszko A, Toth GP, Christ SA, ElSaidy D, Ottobre JS (1996) Reproductive physiology of yellow perch (Perca flavescens): environmental and endocrinological cues. J Appl Ichthyol 12:139-148

Daufresne M, Boët P (2007) Climate change impacts on structure and diversity of fish communities in rivers. Global Change Biol 13:2467-2478

Daufresne M, Roger MC, Capra H, Lamouroux N (2003) Long-term changes within the invertebrate and fish communities of the 
Upper Rhône River: effects of climatic factors. Global Change Biology 10:124-140

European Commission (2006a) Communication from the Commission on the promotion of inland waterway transport "NAIADES" - an integrated European action programme for inland waterway transport. Office for Official Publications of the European Communities, Luxembourg, p 15

European Commission (2006b) Keep Europe moving-Sustainable mobility for our continent. Office for Official Publications of the European Communities, Luxembourg, p 39

Fisher SJ, Pope KL, Templeton LJ, Willis DW (1996) Yellow Perch spawning habitats in Pickerel Lake, South Dakota. Prairie Nat 28:65-75

Fitzsimons JD, Jonas JL, Claramunt RM et al (2007) Influence of egg predation and physical disturbance on lake trout Salvelinus namaycush egg mortality and implications for life-history theory. J Fish Biol 71:1-16

Gafny S, Gasith A, Goren M (1992) Effect of water level fluctuation on shore spawning of Mirogrex terrasanctae (Steinitz), (Cyprinidae) in Lake Kinneret, Israel. J Fish Biol 41:863-871

Herzig A, Winkler H (1986) The influence of temperature on the embryonic development of three cyprinid fishes, Abramis brama, Chalcalburnus chalcoides mento and Vimba vimba. J Fish Biol 28:171-181

Hofmann H (2007) Characteristics and implications of surface gravity waves in the littoral zone of a large lake (Lake Constance). Dissertation, University of Konstanz, 129 pp

Hofmann H, Lorke A, Peeters F (2008) The relative importance of wind and ship waves in the littoral zone of a large lake. Limnol Oceanogr 53:368-380

Holland LE (1986) Effects of barge traffic on distribution and survival of ichthyoplankton and small fishes in the Upper Mississippi River. Trans Am Fish Soc 115:162-165

Holland LE (1987) Effect of brief navigation-related dewaterings on fish eggs and larvae. North Am J Fish Manag 7:145-147

Hurlbert SH (1984) Pseudoreplication and the design of ecological field experiments. Ecol Monogr 54:187-211

Jöhnk KD, Straile D, Ostendorp W (2004) Water level variability and trends in Lake Constance in the light of the 1999 centennial flood. Limnologica 34:15-21

KLIWA (2006) Regionale Klimaszenarien für Süddeutschland, Heft 9. Arbeitskreis KLIWA, Karlsruhe, p 102

Leira M, Cantonati M (2008) Effects of water-level fluctuations on lakes: an annotated bibliography. Hydrobiologia 613:171-184

Löffler H (1984) Zur Ökologie des Brachsen (Abramis brama (L.)) im Bodensee. Schweiz Z Hydrol 46:147-162

Migaud H, Wang N, Gardeur JN, Fontaine P (2006) Influence of photoperiod on reproductive performances in Eurasian perch Perca fluviatilis. Aquaculture 252:385-393

Mills CA (1981) Egg population dynamics of naturally spawning dace, Leuciscus leuciscus (L.). Environ Biol Fish 6:151-158

Mührle U, Ortlepp J, Rey P (2004) Der Bodensee-Zustand, Fakten, Perspektiven, Internationale Gewässerschutzkommission für den Bodensee (IGKB), Bregenz, $176 \mathrm{pp}$

Niepagenkemper O (2004) Untersuchungen zur Fischfauna im Dortmund-Ems-Kanal. Landesfischereiverband Westfalen und Lippe e.V, Münster, p 119
Nõges P, Järvet A (2005) Climate driven changes in the spawning of roach (Rutilus rutilus (L.)) and bream (Abramis brama (L.)) in the Estonian part of the Narva River basin. Boreal Environ Res 10:45-55

Oberemm A, Fastner J, Steinberg CEW (1997) Effects of microcystinLR and cyanobacterial crude extracts on embryo-larval development of zebrafish (Danio rerio). Water Res 31:2918-2921

Ostendorp W, Schmieder K, Jöhnk K (2004) Assessment of human pressures and their hydromorphological impacts in lakeshores in Europe. Ecohydrol Hydrobiol 4:379-395

Oyen FGG, Camps LECMM, Wendelaar Bonga SE (1991) Effects of acid stress on the embryonic development of the common carp (Cyprinus carpio). Aquatic Toxicol 19:1-12

Ozen O, Noble RL (2002) Relationship between water level fluctuations and largemouth bass spawning in a Puerto Rico Reservoir. In: Philipp DP, Ridgway MS (eds) Black bass: ecology, conservation, and management. American Fisheries Society, Bethesda, pp 213-220

Peters L, Scheifhacken N, Kahlert M, Rothhaupt K-O (2005) An efficient in situ method for sampling periphyton in lakes and streams. Archiv für Hydrobiol 163:133-141

Peters L, Wetzel MA, Traunspurger W, Rothhaupt K-O (2007) Epilithic communities in a lake littoral zone: the role of watercolumn transport and habitat development for dispersal and colonization of meiofauna. J North Am Benthol Soc 26:232-243

Poncin P, Philippart JC, Ruwet JC (1996) Territorial and nonterritorial spawning behaviour in the bream. J Fish Biol 49:622626

Potts GW, Wootton RJ (1984) Fish reproduction: strategies and tactics. Academic Press, London, p 410

Probst WN, Stoll S, Peters L, Fischer P, Eckmann R (2009) Lake water level increase during spring affects the breeding success of bream Abramis brama (L.). Hydrobiologia 632:211-224

Rupp R (1965) Shore-spawning and survival of eggs of the American Smelt. Trans Am Fish Soc 94:160-168

Sharma S, Jackson DA, Minns CK, Shuter BJ (2007) Will northern fish populations be in hot water because of climate change? Global Change Biol 13:2052-2064

Spence R, Ashton R, Smith C (2007) Oviposition decisions are mediated by spawning site quality in wild and domesticated zebrafish, Danio rerio. Behaviour 144:953-966

Steer MA, Moltschaniwskyj NA (2007) The effects of egg position, egg mass size, substrate and biofouling on embryo mortality in the squid Sepioteuthis australis. Rev Fish Biol Fish 17:173-182

Sutela T, Vehanen T (2008) Effects of water-level regulation on the nearshore fish community in boreal lakes. Hydrobiologia 613:13-20

Thorp JH (1988) Patches and the responses of lake benthos to sunfish nest-building. Oecologia 76:168-174

Wittkugel C (2002) Entwicklung eines Laichhabitatsindexes für uferlaichende Fischarten im Bodensee. Dissertation, University of Konstanz, 124 pp

Zeh M, Ritter E, Ribi G (1989) Spawning and egg development of Perca fluviatilis in Lake Zürich. Aquat Sci 51:100-107

Zorn SA, Margenau TL, Diana JS, Edwards CJ (1998) The influence of spawning habitat on natural reproduction of muskellunge in Wisconsin. Trans Am Fish Soc 127:995-1005 